\title{
Life history dynamics of the limpet Patelloida alticostata in intertidal and subtidal environments
}

\author{
W. J. Fletcher* \\ Zoology Building, School of Biological Sciences, University of Sydney, NSW 2006, Australia
}

\begin{abstract}
Population dynamics and reproductive biology of the acmaeid limpet Patelloida alticostata were investigated on a rocky intertidal platform and on an adjacent shallow subtidal reef in New South Wales, Australia. The intertidal population had a higher density than the subtidal population. Intensity of recruitment of juveniles to the intertidal region was also greater. Growth rate of individuals was higher in subtidal regions and inversely correlated with population density. In contrast, mortality rate was positively correlated with density; intertidal individuals had an annual mortality rate of $80 \%$ whilst subtidally this was only $36 \%$. The maximum and mean sizes of subtidal individuals were therefore much greater than those in the intertidal area. Both populations spawned at similar times of the year: March, May and October. Two different estimations of reproductive effort of individuals from the 2 populations indicated that individuals had similar investments despite the large differences in other population characteristics. It was concluded that this species does not conform to any generalised theory concerning life history patterns. Nonetheless, the discovery of the large flexibility in responses of neighbouring populations will be important in any examination of the role of this species in the structure of the New South Wales marine community.
\end{abstract}

\section{INTRODUCTION}

The determination of the biological or life history characteristics of a species is a fundamental requirement for any ecological study. Basic knowledge of growth, mortality, recruitment and reproduction are invaluable in any analysis of the structure and dynamics of biological communities (Underwood 1979. Creese 1981, Underwood et al. 1983). Furthermore, such studies have been, in part, responsible for the burgeoning number of theories accounting for the different life history patterns found both among and within a species. These theories suggest that the number of successful offspring an individual produces should be maximised by some combination of present versus future investment into either maintenance and growth, or into reproduction (Fisher 1930, see also Stearns 1976 for review). These 'trade-offs' will, supposedly, be related to such factors as the level of competitive ability or the rates of mortality of a species (Williams 1966, Stearns 1976).

\footnotetext{
- Present address: ACIAR Coconut Crab Project, Fisheries Department, PO Box 211, Luganville, Santo, Republic of
} Vanuatu
Stearns (1976) has defined the life history characteristics of a species as a set of co-adapted traits which have resulted from selection in a specific environment. It is more likely, however, that a species has evolved a suite of life history traits which may then be varied within some larger pattern, in response to environmental change or differences (McKillup \& Butler 1979). This phenotypic variation must be accounted for in any assessment of the characteristics of a population or species (Stearns 1976, 1980, Goodman 1979, Brown 1983, Fletcher 1984a). Such variation is likely to have important consequences in determining the distribution of species, or their persistence within any area (den Boer 1968, 1981), especially in those organisms with dispersive larvae (Underwood 1979, Fletcher 1984a). Moreover, differences among natural populations need to be assessed before predictions can be made on how perturbations may affect their dynamics (Underwood et al. 1983).

Many studies have investigated the life history characteristics of different species, often under different environmental conditions, relating any variations found to differences in their respective regimes of selection. But, while contrasts in traits are often obvious at these higher taxonomic levels, reasons for these 
differences are not as easily understood (Stearns 1980). Any attempt to analyse the differences among species will be confounded if there are also differences among habitats. It is impossible in such studies to determine whether the observed differences were due to the habitat, the species, or an interaction between the two (Fletcher 1984a). Thus, investigations of the biology of one species within differing environments are important to our understanding of patterns of life history (Sutherland 1970, Stearns 1976, Fletcher 1984a). Furthermore, they enable a more comprehensive description of population dynamics and ultimately, may become an essential part of any ecological study of a species (Sutherland 1970).

Studies of intertidal gastropods, especially limpets, have found marked intraspecific variations in the population characteristics in a number of species (Ballantine 1961, Sutherland 1970, Branch 1975, Lewis \& Bowman 1975, Choat 1977, Thompson 1979, 1980, Creese 1980a, Workman 1983, Fletcher 1984a, b, c). In addition, large differences have been found between intertidal and subtidal populations for one species, Cellana tramoserica (Fletcher 1984b)

In this study, the population dynamics and life history patterns of the acmaeid limpet Patelloida alticostata (Angas) were investigated in 2 contrasting habitats; an intertidal platform and an adjacent shallow subtidal reef in New South Wales, Australia. This species has been studied previously within the same intertidal region in New South Wales by Creese (1978, 1980b, 1981) and Fletcher \& Creese (1985). It has also been examined in the intertidal regions of Victoria (Parry 1982a, b) and Western Australia (Black 1977). No investigation of any subtidal population of $P$. alticostata has been done. This study, therefore, will provide information on the similarity in the dynamics of the intertidal population of $P$. alticostata in studies done 6 yr apart and also provides data on a population of subtidal limpets, few of which have been studied (Fletcher $1984 \mathrm{c}$ ). The results from the 2 populations will be compared to those found for other species of limpets. Finally, the patterns of life history and reproductive effort of the 2 populations will be compared according to current theories.

\section{MATERIALS AND METHODS}

Study sites. This study was done at the Cape Banks Scientific Marine Research Area on the northern headland of Botany Bay, New South Wales, Australia. The intertidal population of Patelloida alticostata occupied the same low sandstone reef as used by Creese (1978, 1981) for his studies on this species. The subtidal population was situated offshore from the intertidal site at a depth of 1 to $3 \mathrm{~m}$. This region is composed of large boulders $\left(>3 \mathrm{~m}^{2}\right)$ covered largely by encrusting coralline algae in association with large numbers of the sea urchin Centrostephanus rodgersii (Fletcher 1987). All sampling in this site was restricted to the surfaces of these boulders.

Density. The densities of each population of Patelloida alticostata were estimated in most months from November 1981 to June 1983 (intertidal) or to November 1983 (subtidal) by counting the number of individuals in 15 random quadrats (both populations) and 15 permanent quadrats (subtidal site only). Adults, juveniles and recruits were distinguished in all counts (see Table 1 for sizes and summary of details). A further

Table 1. Sizes and summary of methods used in sampling Patelloida alticostata at the 2 sites

\begin{tabular}{|lcc|}
\hline & Intertidal & Subtidal \\
\hline Sampling Period & Nov 1981-May 1983 & Nov $1981-$ Nov 1983 \\
Size of: & & \\
$\quad$ recruits & $<3 \mathrm{~mm}$ & $<4 \mathrm{~mm}$ \\
juveniles & $<14 \mathrm{~mm}$ & $<20 \mathrm{~mm}$ \\
adults & $>14 \mathrm{~mm}$ & $>20 \mathrm{~mm}$ \\
Size of quadrat & $0.1 \mathrm{~m}^{2}$ & $0.25 \mathrm{~m}^{2}$ \\
No. of quadrats & $15 \mathrm{random}$ & 15 permanent \\
& & 15 random \\
Sizes of individuals & $15-24 \mathrm{~mm}$ & $25-45 \mathrm{~mm}$ \\
collected for repro- & & \\
ductive analyses & & \\
\hline
\end{tabular}

estimate of the density of the subtidal population was obtained by counting the total numbers of individuals on 3 permanent study boulders (approximately $2 \mathrm{~m}^{2}$ in area). This meant that both large- and small-scale changes in the density of this subtidal population could be assessed.

Size frequencies. At each sampling, maximum shell lengths of individuals within the quadrats were measured to the nearest $0.5 \mathrm{~mm}$. For the subtidal population, shell lengths of all individuals on the permanent boulders, along with a number of randomly selected boulders, were also measured to increase the sample size.

Growth. Subtidal. The growth rates of this population were estimated by 2 methods:

(a) Individuals were marked by 1 or 2 small file marks on their shells. The limpet shells were divided into 5 regions (front, back, left, right and top). File marks were made in 2 of these regions which meant that in any one area 32 combinations were possible. Approximately 50 to 60 of these marked individuals (from a number of areas) were measured to the nearest $0.5 \mathrm{~mm}$ at monthly intervals from November 1981 to December 1982. These monthly measurements were analysed by calculating the regression of increment of 
growth against initial size. From the monthly regression calculations, the slope of the curve was used to estimate both the change in this rate among months and also to construct a continuous growth curve. This curve began at a shell length of $4 \mathrm{~mm}$ with the calculated increment of growth added monthly using the formula I $=a \mathrm{x}+b$, where $\mathrm{I}=$ increment of growth, $a=$ slope, $b=Y$ intercept of the monthly estimates, and $\mathrm{x}=$ initial size of the individual (see also Fletcher $1984 \mathrm{~b}$ ). This procedure was repeated until the curve approached the asymptote.

(b) A second estimate of growth used the monthly size frequency data, whereby the mean sizes of cohorts were followed through time. The individual cohorts were separated using the method developed by Underwood (1975) from Cassie (1954). This generally involves using probability paper to distinguish between adjacent age classes. In cases where these points of inflection were ambiguous, however, probits were calculated and a regression technique was used to separate them (Underwood 1975).

Intertidal. Calculation of the rate of shell growth in this population was also originally attempted by the measurement of marked individuals (paint dots) at regular intervals. Unfortunately, this method proved unsatisfactory because of the dampness of the shells, which substantially increased the loss of paint marks between sampling periods. This method was, therefore, abandoned after 9 mo making estimates of seasonal changes in growth over the entire year impossible. Nonetheless, growth could still be estimated using the size frequency method (see above). Also a modified version of the growth equation was calculated whereby in the months where the data from marked limpets were not collected (August to October), the mean value from all the other 9 mo was used.

Mortality. Mortality rates of both populations were estimated by 2 methods:

(a) By the reduction in the density of individual size frequency cohorts through time;

(b) By the monthly calculation of the Beverton-Holt moment estimate of mortality:

$Z=K\left(L_{\infty}-L_{x}\right) /\left(L_{x}-L_{c}\right) \quad$ (Beverton \& Holt 1957)

where $\mathrm{Z}=$ instantaneous rate of mortality; $\mathrm{L}_{\mathrm{x}}=$ mean size of individuals; $\mathrm{L}_{c}=$ size at recruitment; and $\mathrm{L}_{\infty}$ and $K=$ constants from the Richards' growth equation (Richards 1959, see also Ebert 1973, 1982). This equation uses the fact that the size frequency distribution of a population is the result of previous growth, mortality and recruitment (Ebert 1973). The mean rates of mortality (plus standard deviation) for the 2 populations were determined using the monthly calculation of the Beverton-Holt equation during the period of monitoring. The estimates of mortality using this technique were compared to those calculated from the reduction in the density of each cohort over time.

Reproductive and somatic cycles. Monthly collections of 15 to 20 individuals reflecting the size range of adults from each population (see Table 1 for sizes) were made from November 1981 to November 1982. The specimens were then placed into a $10 \%$ formalinseawater solution and left for at least $4 \mathrm{wk}$ to allow the gonads to harden which aids in their dissection (Underwood 1974, Creese, 1980a). After this period, the shell length of each individual was measured and the gonad dissected from the remaining somatic tissue. Each part was wet weighed to the nearest $0.1 \mathrm{mg}$, and the reproductive/spawning cycle and the somatic cycle of each population determined by calculating a monthly gonad index (mean gonad/somatic ratio) and a monthly somatic index ([mean somatic wt $]^{0.5} /$ shell length). An additional measure of female gonadal condition was determined by smearing small amounts of ovary from 3 individuals onto slides and determining the proportions of the different oocyte stages (previtellogenic, immature and mature).

Reproductive effort. The reproductive effort of each population was initially estimated using the technique described in Fletcher (1984a). The reproductive effort of a population is defined as the relative amount of female gonadal material, compared to somatic weight, spawned in 1 yr. This method utilises the monthly calculation of the gonad/somatic $(\mathrm{g} / \mathrm{s})$ ratio over a period of at least 1 yr. These monthly estimates were analysed by a 3-factor analysis of variance (population, sex month) and the amount of gonad spawned was calculated from the sum of each significant reduction in the $\mathrm{g} / \mathrm{s}$ ratio between months. This measure is biased if the $\mathrm{g} / \mathrm{s}$ ratio declines solely as a result of increased mean somatic weight between months. To guard against this, the $\mathrm{g} / \mathrm{s}$ ratio for each month was standardised using the mean somatic index for the year of sampling as a scaling factor (Fletcher 1984a).

An alternative estimate of reproductive effort was calculated using the formula $G / G+P$; where $G=$ production of gonad material during a set period (1 yr), and $P=$ production of somatic tissue over the same period. This was calculated for each population.

\section{RESULTS}

\section{Density and recruitment}

Subtidal population

The density of adults within this population did not vary greatly during the 24 mo of sampling (Fig. 1a), with mean density fluctuating around $12 \mathrm{~m}^{-2}$. The 

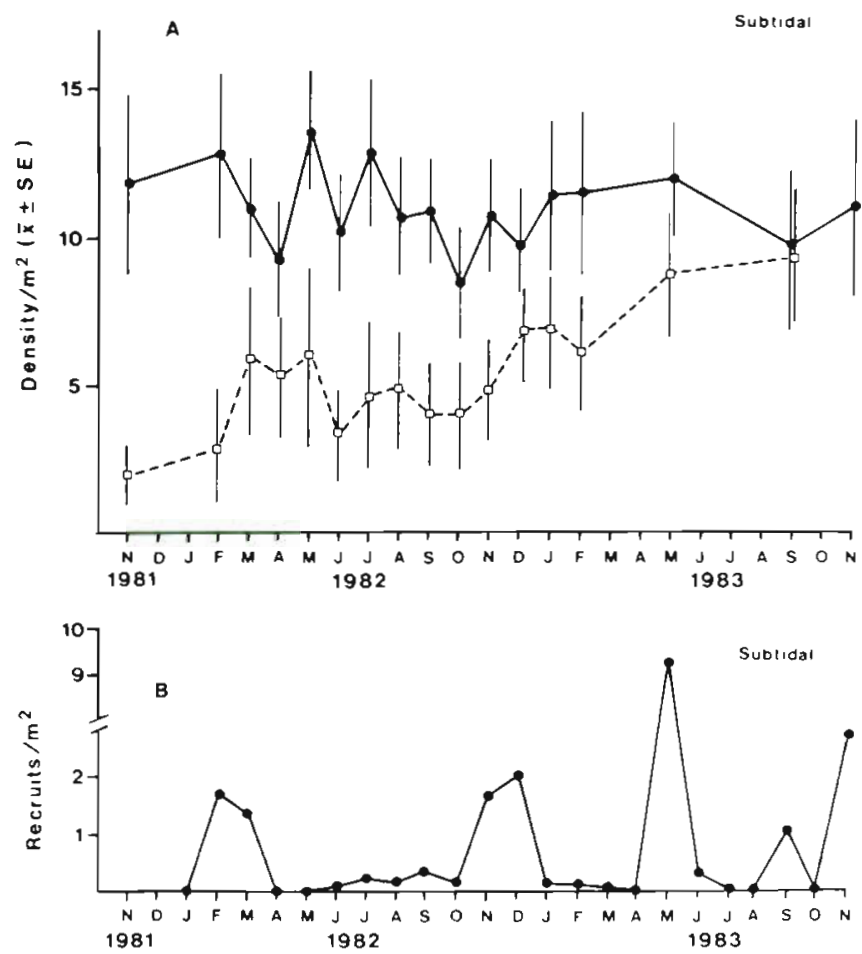

Fig. 1. Patelloida alticostata at the subtidal site. (A) Mean density per $\mathrm{m}^{2}( \pm \mathrm{SE}$ ) of adults (>20 $\mathrm{mm}$ shell length) $(\bullet-\bullet)$ and juveniles $(>4 \mathrm{x}<20 \mathrm{~mm})(\square--\square)$. (B) Mean density per $\mathrm{m}^{2}$ of recruits ( $<4 \mathrm{~mm}$ shell length)

number of adults on the permanent boulders was also reasonably stable throughout the period of the study (Table 2).

The density of juveniles did vary within the course of the study (Fig. 1a). Increases were found in March and December 1982, corresponding to periods following

Table 2. Patelloida alticostata. Number of adults and juveniles (including recruits) on 3 monitored boulders in the subtidal region. $(-)$ indicates no observations made

\begin{tabular}{|lrrrrrr|}
\hline Date & \multicolumn{2}{c}{ Boulder 1 } & \multicolumn{2}{c}{$\begin{array}{c}\text { Boulder 2 } \\
\text { Adult Juvenile }\end{array}$} & $\begin{array}{c}\text { Boulder 3 } \\
\text { Adult Juvenile }\end{array}$ & Adult Juvenile \\
\hline Feb 1982 & 27 & 5 & 18 & 7 & - & - \\
Apr 1982 & 27 & 6 & 14 & 9 & 22 & 5 \\
May 1982 & 26 & 5 & 14 & 10 & 20 & 8 \\
Jun 1982 & 25 & 17 & 13 & 3 & - & - \\
Jul 1982 & 29 & 14 & 16 & 12 & - & - \\
Aug 1982 & 24 & 9 & 15 & 16 & 18 & 8 \\
Sep 1982 & 22 & 14 & 14 & 14 & - & - \\
Oct 1982 & 26 & 8 & 15 & 5 & - & - \\
Nov 1982 & 27 & 22 & 17 & 14 & - & - \\
Dec 1982 & 29 & 14 & 11 & 11 & - & - \\
Jan 1983 & 23 & 14 & 21 & 4 & - & - \\
Feb 1983 & 26 & 14 & 23 & 10 & - & - \\
May 1983 & 27 & 48 & - & - & - & - \\
Sep 1983 & 29 & 41 & - & - & 23 & 10 \\
Nov 1983 & 38 & 55 & - & - & - & - \\
\hline
\end{tabular}

peaks in recruitment. These increases were discernible for 3 or more months until some juveniles outgrew this size, or mortality had reduced their numbers. The mean number of juveniles appeared to increase throughout the 24 mo of monitoring both in quadrat estimates and on 2 of the boulders.

Recruitment occurred in February/March and November/December of 1982; and May and November of 1983 (Fig. 1b). These peaks differed in magnitude; the mean density of recruits in May $1983\left(9.3 \mathrm{~m}^{-2}\right)$ was much greater than in any other sample, where the densities of recruits were usually about $2 \mathrm{~m}^{-2}$.

\section{Intertidal population}

The density of adults showed a seasonal cycle of abundance (Fig. 2a). The peaks of abundance occurred in winter (July to September), and periods of decline occurred during summer (November to March) of both years of the study.

The numbers of juveniles increased in December and January 1982, then decreased in February and March, but there was no concomitant increase in adult density. In fact, as mentioned above, the adult density also declined. This indicates that the drop in juvenile density during the summer was probably not solely due to juveniles growing to adult size. Another increase in the density of juveniles occurred in May to July 1982. This time, the decrease was accompanied by an increase in adult density. The third main increase in the density of juveniles, in January 1983, was again followed by a decrease in density in February and March, which was not translated into an increase in adult density.

In the intertidal population recruitment occurred in November/December 1981; a smaller number recruited during March to May and July to September 1982; a large peak occurred in December 1982 and January 1983 (Fig. 2b).

\section{Growth}

\section{Subtidal population}

The growth of individuals was estimated by monitoring marked limpets, and by following cohorts from monthly size frequency distributions. There was little seasonal pattern to variations in the rate of shell growth of individually marked limpets. These fluctuations were also not significantly correlated with the growth of gonadal material $(r=-0.46, \mathrm{n}=12, \mathrm{p}>0.05)$.

In February 1982, there were 2 identifiable age cohorts, A and B (it was likely that Cohort A consisted 

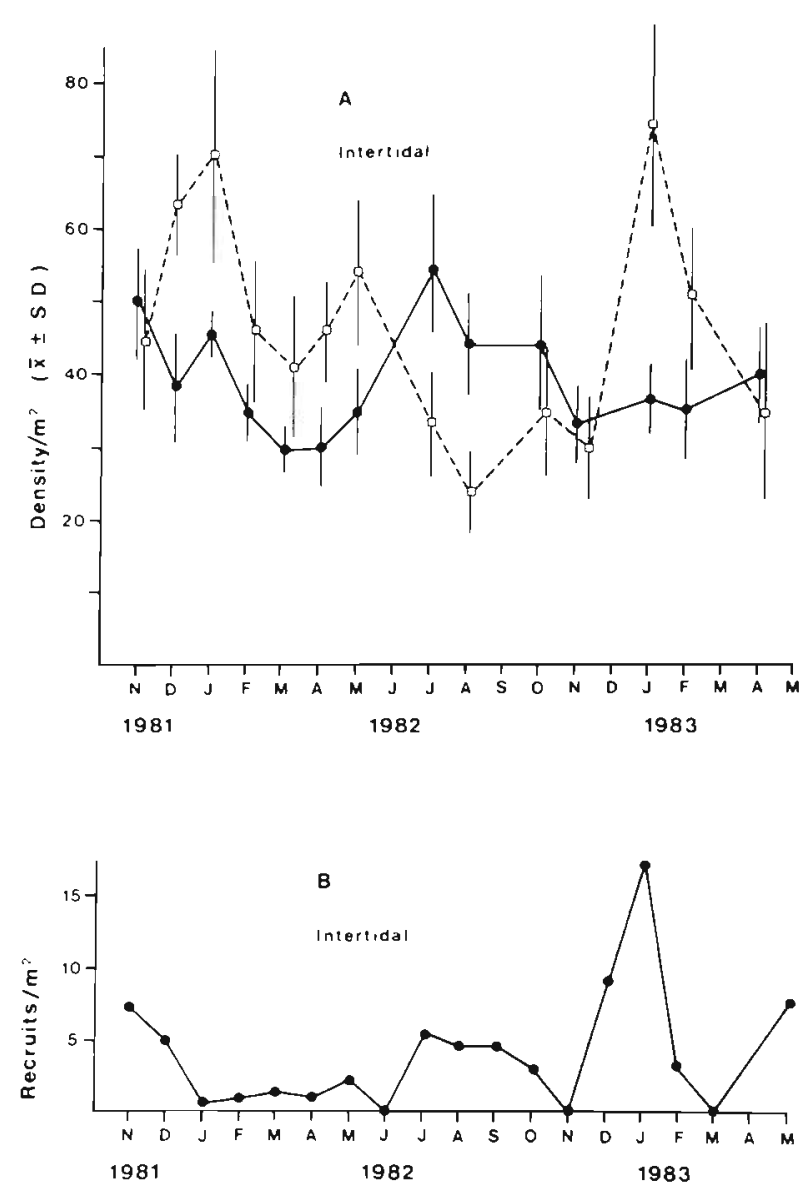

Fig. 2. Patelloida alticostata at the intertidal site. (A) Mean density per $\mathrm{m}^{2}( \pm \mathrm{SD}$ ) for adults (shell length $>14 \mathrm{~mm})(\bullet)$ and juvenile recruits $(<14 \mathrm{~mm})(0-\cdots)$. (B) Mean density per $\mathrm{m}^{2}$ of recruits (shell length $<4 \mathrm{~mm}$ )

of more than one age class), in the size frequency distribution. In February 1983, there were 4 cohorts (A, B, C, D); and in November 1983, there were 5 cohorts (A, B, C, D, E) (Fig. 3). From these, an estimate of the continuous increase in shell length was calculated by joining cohorts which were similar sizes in different years (which assumes that growth is equivalent for any cohort from one year to the next; see also Underwood 1975). Thus, using the observed increases in sizes of Cohorts A, B and D for this population gave an estimate of growth for $3.5 \mathrm{yr}$ (Fig. 4). The curve generated by this method was compared to the estimate of shell growth based on the monthly measurements of marked individuals. Both curves gave very similar results which suggests that either estimate was reliable (Fig. 4).

These limpets reached a shell length of $20 \mathrm{~mm}$ after $1 \mathrm{yr}$ which is the approximate size of sexual maturity for this population. Growth continued at a relatively constant rate for a further 3 yr when the shell reached a size of approximately $40 \mathrm{~mm}$. The maximum size of $48 \mathrm{~mm}$ was probably attained after some 6 to $7 \mathrm{yr}$.

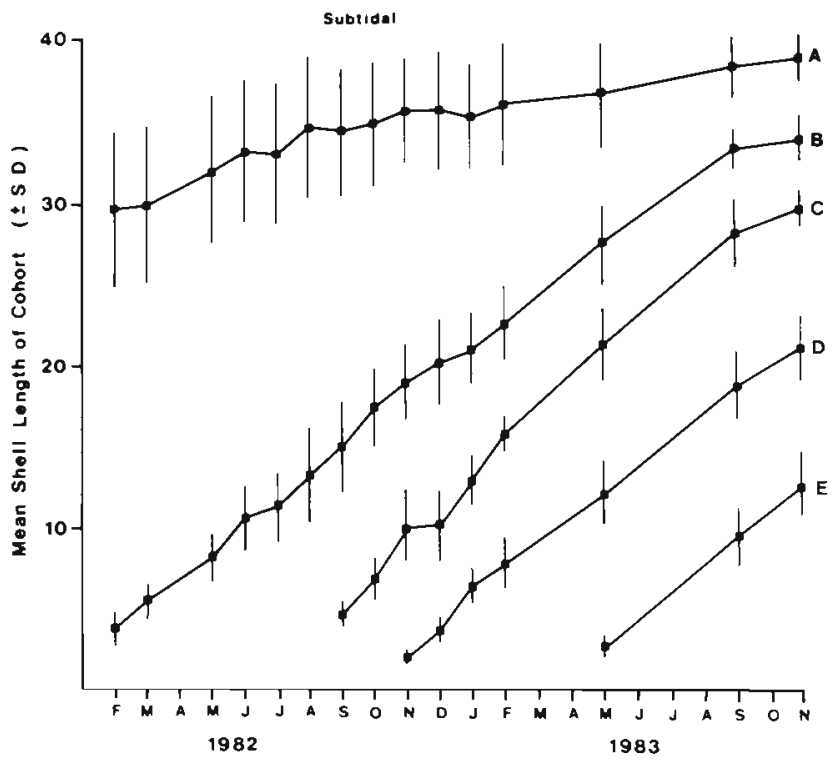

Fig. 3. Patelloida alticostata at the subtidal location. Increase in mean shell length $(\mathrm{mm} \pm \mathrm{SD})$ of age-cohorts

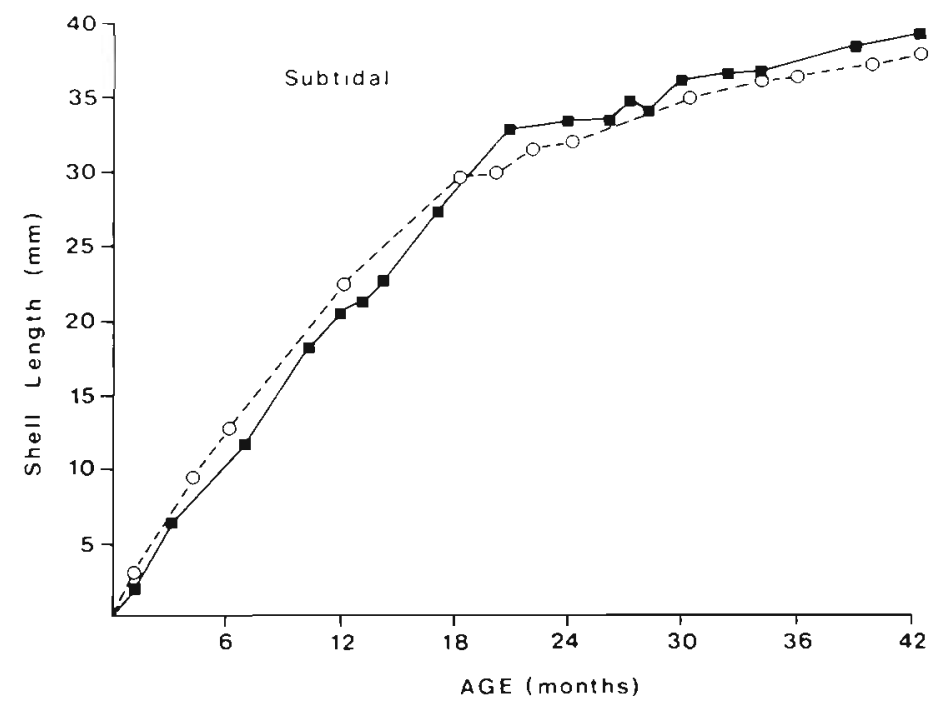

Fig. 4. Patelloida alticostata. Continuous growth curve in the subtidal region, as estimated from the increase in shell length of age-cohorts $(\longrightarrow$ ) and by the measurement of marked individuals from the subtidal site $\left(0-\mathrm{-}_{-0}\right)$

\section{Intertidal population}

The size frequency distributions of this population were difficult to analyse because of the large number of size cohorts present (Fig. 5). There were 5 cohorts in November 1981 (A, B, C, D, E), 5 in November 1982 (B $+C, E, F, G, H)$ and 7 in April $1983(B+C, D, E, F, G$, $\mathrm{H}, \mathrm{I})$. The continuous growth curve calculated from Cohorts I, C, and E of this study were compared with the curve constructed from the monthly data on the 


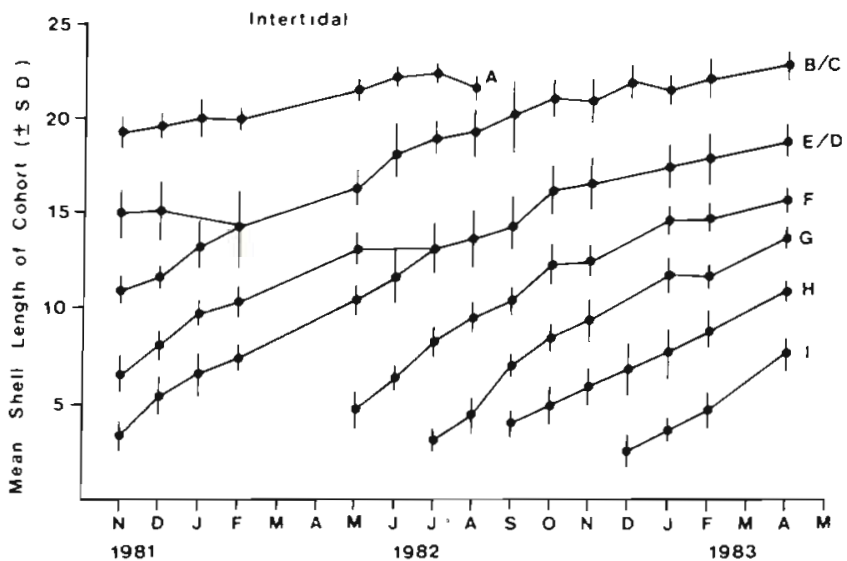

Fig. 5. Patelloida alticostata. Increase in mean shell length $(\mathrm{mm} \pm \mathrm{SD}$ ) of age-cohorts from the intertidal location

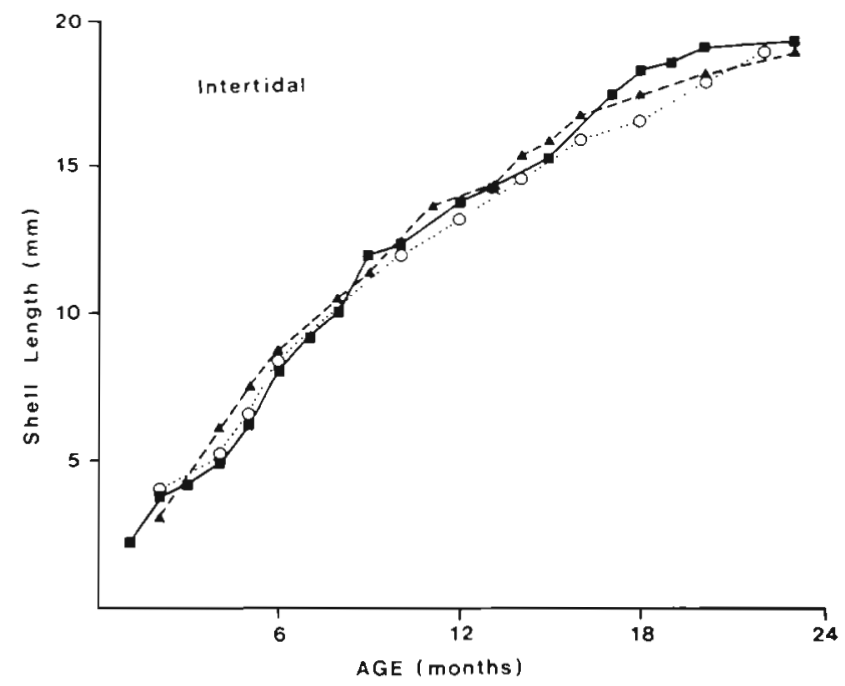

Fig. 6. Patelloida alticostata. Continuous growth curve in the intertidal region, as estimated from the increase in shell length of age-cohorts (-), and by the measurement of marked individuals from the intertidal site $(\mathbf{\Delta - 1} \mathbf{-})$; plus estimates based on the increase in the shell length of age-cohorts of this population from Creese $(1978,1981)(0 \cdots \cdots)$

marked limpets, and also with the curve generated by the increase in size of Cohorts I and C from Creese (1978). All 3 curves gave similar results (Fig. 6), and showed that a shell length of $14 \mathrm{~mm}$ was reached after $1 \mathrm{yr}$. The growth rate was relatively consistent up to approximately $19 \mathrm{~mm}$ shell length ( 2 yr old). After this, growth slowed, with shell length approaching a maximum of $22 \mathrm{~mm}$.

\section{Mortality}

\section{Subtidal population}

Two estimates of the percentage annual mortality for this population were calculated. One used the reduc-
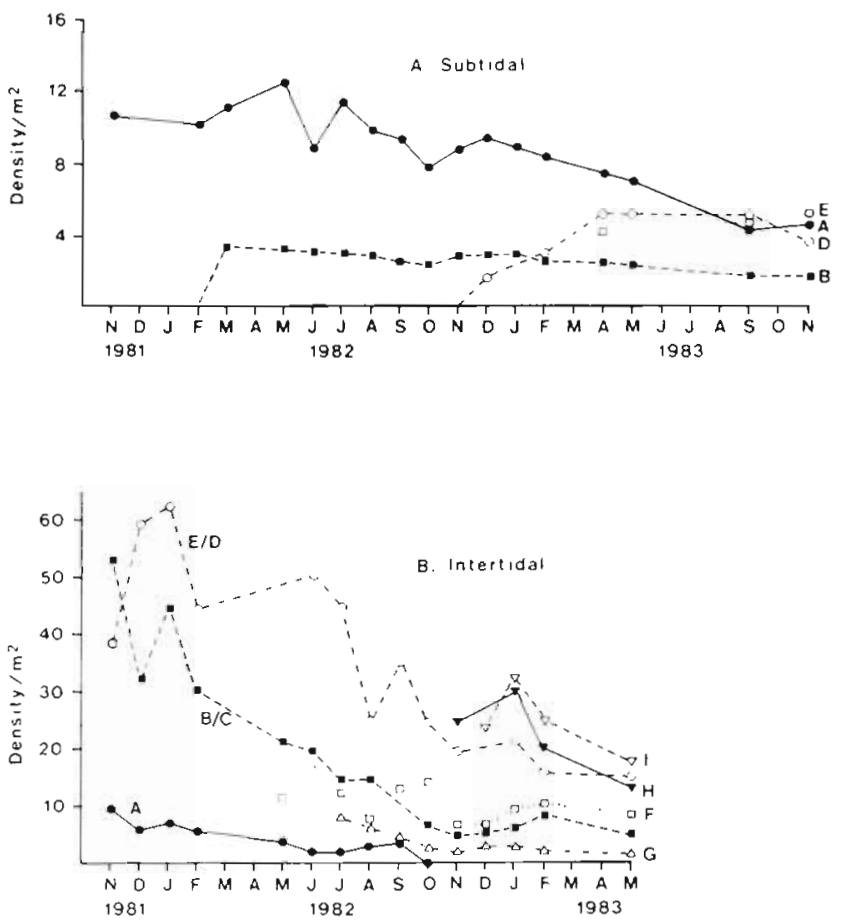

Fig. 7. Patelloida alticostata. Mean density per $\mathrm{m}^{2}$ of the agecohorts from (A) the subtidal site, (B) the intertidal site

tion in the density of size cohorts over time (Fig. 7a); the other used the monthly calculation of the BevertonHolt equation (see 'Materials and Methods').

The mortality rate in the subtidal population was relatively constant for both adults and juveniles. The density of Cohort A decreased slowly during the 2 yr of study (Fig. 7a). Cohort B also decreased slowly after it recruited in March 1982. Cohort D initially increased in density during the first few months after recruitment. This increase was partly due to an extended period of recruitment (Fig. 1b), but a percentage of the new recruits may have been missed in the early samples. The mean estimate of mortality utilising this method suggested that $36 \%$ of adult individuals died per year (Table 3).

The Beverton-Holt equation calculated a mean yearly rate of mortality of $39 \%$ (Table 3 ). This estimate is very close to the previous one. Thus, both estimates of mortality indicated that the maximum lifespan of an individual from this population would be approximately 7 yr.

\section{Intertidal population}

The 2 methods of calculating mortality (reduction in cohort density [Fig. 7b] and calculation of the BevertonHolt equation) estimated that the mortality rate for the intertidal population was close to $80 \%$ per year (Table 4). It appeared from the numerical decreases of 
Table 3. Patelloida alticostata. Estimate of \% annual mortality of the subtidal population, calculated (A) by the reduction in density of age-cohorts, and (B) by the monthly calculation of the Beverton-Holt moment estimate

\begin{tabular}{|c|c|c|c|}
\hline \multicolumn{4}{|c|}{$\begin{array}{l}\text { Cohort A: } 33 \% \text { per year } \\
\text { Cohort B: } 39 \% \text { per year } \\
\text { Mean }=36 \% \text { per year }\end{array}$} \\
\hline \multicolumn{4}{|c|}{ B. Beverton-Holt estimates } \\
\hline Month & Estimate & Month & Estimate \\
\hline Feb 1982 & $36 \%$ & Nov 1982 & $36 \%$ \\
\hline Mar 1982 & $51 \%$ & Dec 1982 & $36 \%$ \\
\hline May 1982 & $36 \%$ & Jan 1983 & $38 \%$ \\
\hline Jun 1982 & $33 \%$ & Feb 1983 & $32 \%$ \\
\hline Jul 1982 & $27 \%$ & May 1983 & $70 \%$ \\
\hline Aug 1982 & $24 \%$ & Sep 1983 & $50 \%$ \\
\hline Sep 1982 & $24 \%$ & Nov 1983 & $75 \%$ \\
\hline Oct 1982 & $24 \%$ & & \\
\hline \multicolumn{4}{|c|}{$\begin{aligned} \text { Mean } & =39 \% \pm 15 \% \\
K & =0.72\end{aligned}$} \\
\hline
\end{tabular}

Table 4. Patelloida alticostata. Estimate of \% mortality of the intertidal population calculated (A) by the reduction in density of age-cohorts, and (B) by monthly calculation of the Beverton-Holt moment estimate

\begin{tabular}{|c|c|c|c|}
\hline \multicolumn{4}{|c|}{ A. Cohort estimates } \\
\hline Cohort & Juvenile & Adult & Yearly \\
\hline A & - & $8 \%$ & $100 \%$ \\
\hline $\mathrm{B} / \mathrm{C}$ & $14 \%$ & $6 \%$ & $90 \%$ \\
\hline$D / E$ & $6 \%$ & $5 \%$ & $60 \%$ \\
\hline$F$ & $5.5 \%$ & - & $65 \%$ \\
\hline $\mathrm{H}$ & $6 \%$ & - & - \\
\hline I & $10 \%$ & - & $\begin{aligned} & - \\
\text { Mean } & =79 \%\end{aligned}$ \\
\hline \multicolumn{4}{|c|}{ B. Beverton-Holt estimates } \\
\hline Month & Estimate & Month & Estimate \\
\hline Nov 1981 & $95 \%$ & Jul 1982 & $52 \%$ \\
\hline Dec 1981 & $117 \%$ & Aug 1982 & $65 \%$ \\
\hline Jan 1982 & $98 \%$ & Sep 1982 & $96 \%$ \\
\hline Feb 1982 & $95 \%$ & Oct 1982 & $90 \%$ \\
\hline Mar 1982 & $86 \%$ & Nov 1982 & $91 \%$ \\
\hline Apr 1982 & $92 \%$ & Dec 1982 & $100 \%$ \\
\hline May 1982 & $79 \%$ & Jan 1983 & $95 \%$ \\
\hline Jun 1982 & $75 \%$ & Feb 1983 & $63 \%$ \\
\hline \multicolumn{4}{|c|}{$\begin{aligned} \text { Mean } & =86 \% \pm 16 \% \\
K & =0.86\end{aligned}$} \\
\hline
\end{tabular}

the size cohorts that the mortality rates were greater for juveniles than for adults (Fig. 7b) but the percentage reductions were similar (Table 4). The maximum life expectancy for this population was between 2.5 and $3 \mathrm{yr}$. This is consistent with estimates of growth, the mean shell length of cohorts at the time prior to their disappearance, and the maximal shell size observed (24 mm).

\section{Reproductive cycles}

Subtidal population

Spawning, as indicated by a significant decrease in the $\mathrm{g} / \mathrm{s}$ ratio of individuals between consecutive months (Fig. 8a), and a decrease in the proportion of mature oocytes in gonads (Fig. $8 b$ ) occurred a number of times during the year of monitoring. These periods of spawning differed in their intensity and duration. Decreases in both indices occurred during the months November 1981 to March 1982, and in May 1982, while the largest decreases (in terms of $\mathrm{g} / \mathrm{s}$ ratios) occurred in October and November 1982. Furthermore, in the
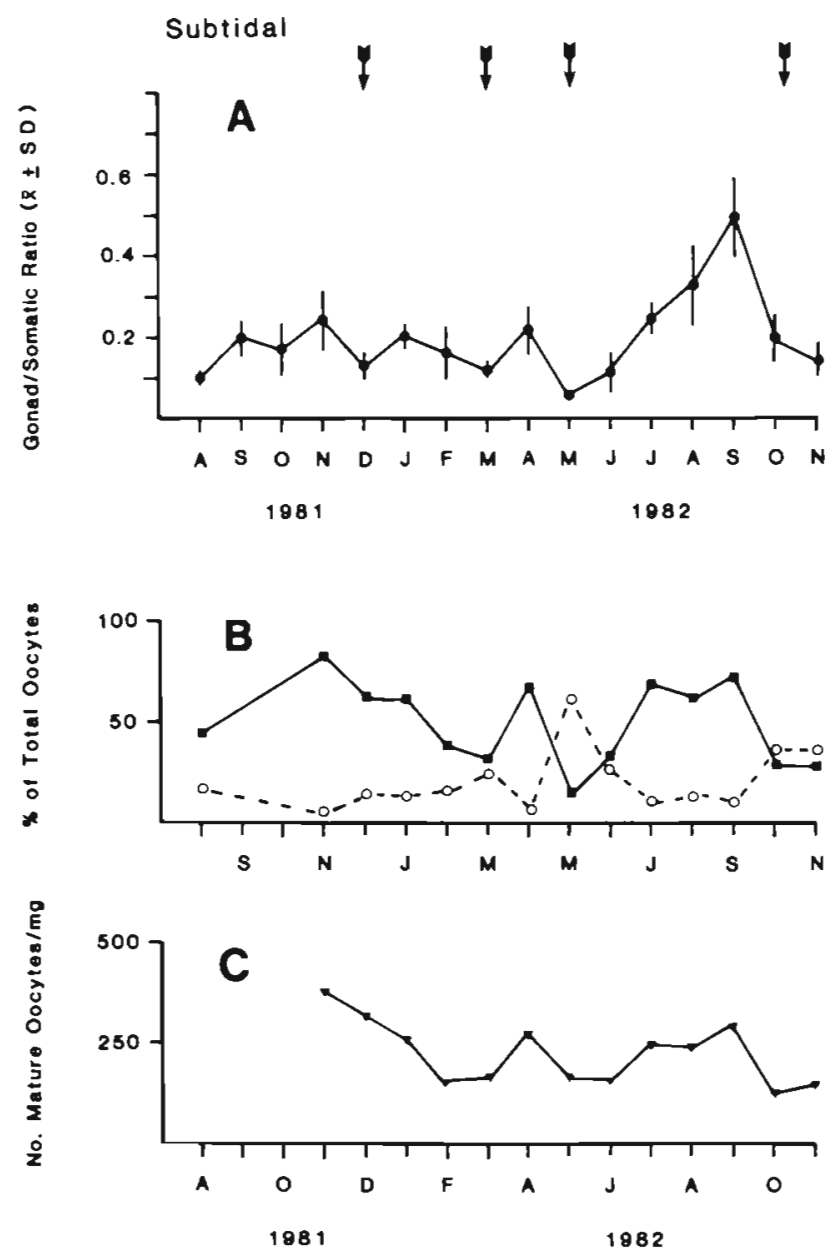

Fig. 8. (A) Patelloida alticostata. Reproductive cycle of the subtidal population (mean of the gonad/somatic ratio of females $\pm \mathrm{SD}$ ). Arrows indicate significant reduction in ratio (indicating spawning) had occurred. (B) Mean percentage of mature ( $\square$ ) and previtellogenic oocytes (0--) from smears of female gonads. (C) Mean number of mature oocytes per mg of ovary 
month prior to each period of spawning, the number of mature eggs per $\mathrm{mg}$ of gonad material was at a maximum ( $\mathrm{x}=350$; Fig. $8 \mathrm{c})$. This value decreased during the spawning period.

\section{Intertidal population}

Decreases in the 2 gonad indices (indicating periods of spawning) of this population were restricted to $4 \mathrm{mo}$ : December 1981, March 1982, May 1982 and October 1982 (Fig. 9A, B). The number of mature eggs per mg of gonad in the months prior to each period of spawning was $\overline{\mathrm{x}}=290$ (Fig. 9C); this had declined after spawning suggesting that a large proportion of the mature oocytes had been shed.
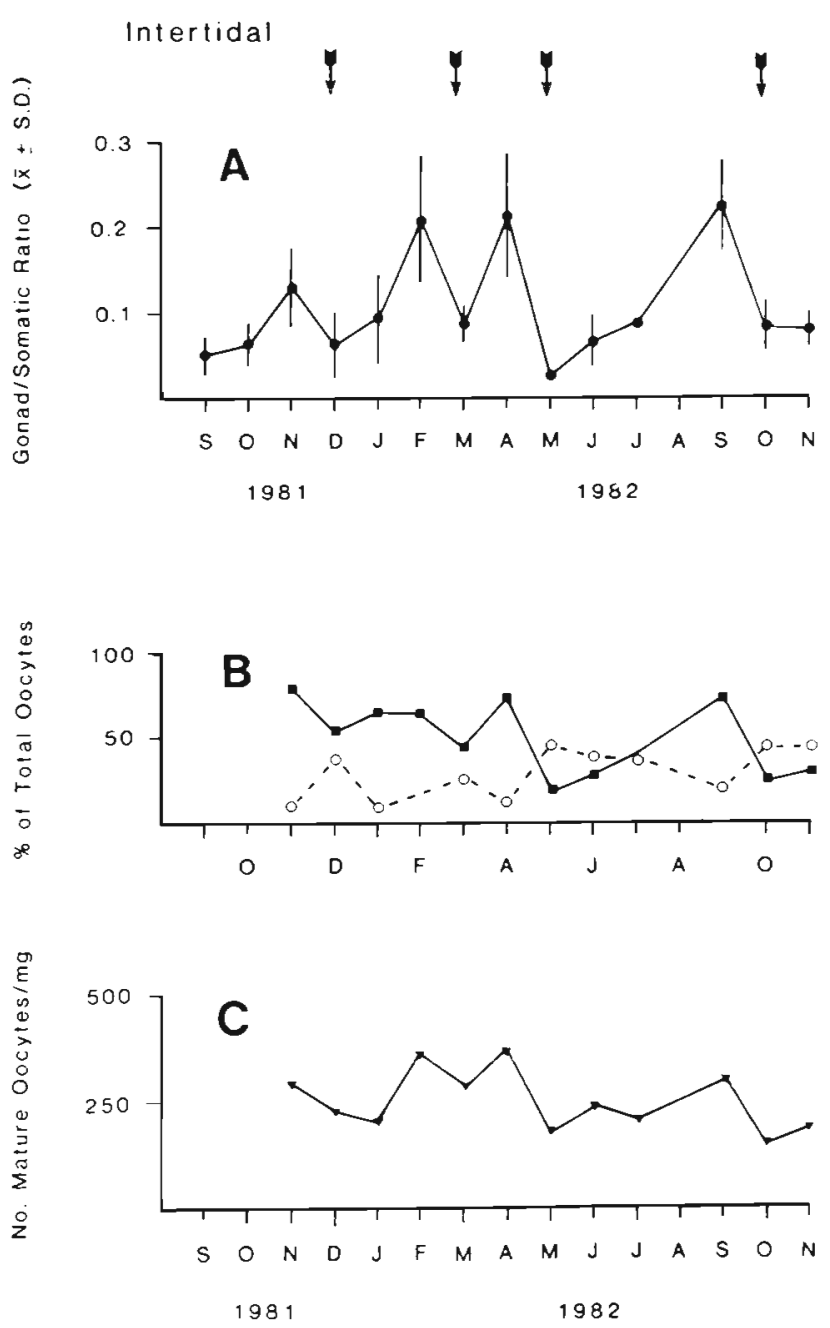

Fig. 9. (A) Patelloida alticostata. Reproductive cycle of the intertidal population (mean of the gonad/somatic ratio of females $\pm S D$ ). Arrows indicate significant reduction in ratio (indicating spawning) had occurred. (B) Mean percentage of mature (-), and previtellogenic oocytes (--o), from smears of female gonads. (C) Mean number of mature oocytes per mg of ovary

\section{Reproductive effort}

The reproductive effort of the subtidal population of Patelloida alticostata, as calculated by the $\mathrm{g} / \mathrm{s}$ method, was slightly greater than that for the intertidal population (Table 5). Because there was no evidence that the $\mathrm{g} / \mathrm{s}$ ratios were affected by differences in shell length within a site either before or after spawning (Table 6),

Table 5. Patelloida alticostata. Reproductive effort of each population as calculated by the total reduction in the gonad/ somatic ratio (females only) summed over the year of sampling

\begin{tabular}{|lcc|}
\hline Month & Subtidal & Intertidal \\
\hline Dec & $11 \%$ & $5.2 \%$ \\
Mar & $8 \% \%$ & $12.6 \%$ \\
May & $12.3 \%$ & $17.8 \%$ \\
Nov & $36.4 \%$ & $15.3 \%$ \\
Total & $67.8 \%$ & $51.0 \%$ \\
\hline
\end{tabular}

Table 6. Relation between the gonad/somatic ratio (females only) and somatic weight in most months before and after spawning occurred

\begin{tabular}{|lccccccc|}
\hline \multirow{2}{*}{ Month } & \multicolumn{3}{c}{ Subtidal population } & \multicolumn{4}{c|}{ Intertidal population } \\
& $r$ & $\mathrm{n}$ & $\mathrm{p}$ & $r$ & $\mathrm{n}$ & $\mathrm{p}$ \\
\hline Dec & 0.3 & 7 & $\mathrm{~ns}$ & 0.6 & 6 & $\mathrm{~ns}$ \\
Feb & -0.2 & 7 & $\mathrm{~ns}$ & 0.3 & 7 & $\mathrm{~ns}$ \\
Mar & -0.21 & 6 & $\mathrm{~ns}$ & -0.22 & 6 & $\mathrm{~ns}$ \\
Apr & -0.16 & 8 & ns & 0.22 & 7 & $\mathrm{~ns}$ \\
May & -0.15 & 8 & ns & -0.055 & 7 & ns \\
Sep & -0.169 & 9 & ns & 0.10 & 8 & ns \\
\hline
\end{tabular}

it is likely that the slight difference between the populations was probably not a result of the subtidal individuals being generally larger than those from the intertidal area.

The second method of calculating the reproductive effort of a population $(\mathrm{G} /[\mathrm{G}+\mathrm{P}])$ used the increase in somatic weight during each year following sexual maturity as the estimate of $\mathrm{P}$ (somatic production). For $G$ (production of gonad material), the age-specific weight of gonad spawned each year following sexual maturity was calculated using the $\mathrm{g} / \mathrm{s}$ estimate of RE to indicate the amount of gonad production as a proportion of somatic weight (Table 5). The age-specific gonad weight was calculated using the age/shell length curves (Fig. 4 \& 6) and the relation between shell length and somatic weight (Fletcher 1984c). Using this second method, the 2 populations had very similar values and these increased within the older age cohorts of each population (Table 7 ). 
Table 7 Patelloida alticostata. Reproductive effort for the 2 populations by the $G /(G+P)$ formula where $G$ and $P$ are the gonadal and somatic productions $\left(g \mathrm{yr}^{-1}\right)$. Age is years after the attainment of sexual maturity

\begin{tabular}{|lllllllll|}
\hline \multicolumn{4}{c}{ Subtidal population } & \multicolumn{4}{c|}{ Intertidal population } \\
Age & $G$ & $P$ & $G /(G+P)$ & Age & $G$ & $P$ & $G / G+P$ \\
\hline 1 & 0.389 & 0.832 & 0.318 & 1 & 0.0611 & 0.0916 & 0.4 \\
2 & 0.854 & 0.53 & 0.617 & 2 & 0.101 & 0.064 & 0.61 \\
3 & 1.187 & 0.442 & 0.728 & & & & \\
\hline
\end{tabular}

\section{DISCUSSION}

There were marked differences in many population variables of this species between the 2 different areas. Studies by others (Sutherland 1970, Branch 1976. Creese 1980b, Thompson 1980, Workman 1983, Fletcher 1984b, 1984c) have also found differences in the density of neighbouring populations of the same species. Thus, in the present study, the intertidal population of Patelloida alticostata had both a greater density and larger fluctuations than did the subtidal population. Such differences have often been associated with extensive variations in both the size structure and dynamics amongst populations.

\section{Recruitment}

Periods of recruitment to the 2 populations occurred at similar times. There were 2 to 3 main recruitment periods per year which usually occurred in November to January and from March to May. These periods of recruitment were similar to those found by Creese (1981) for the intertidal population of this species during 1976-1977, suggesting that recruitment may occur at similar times in different years. Furthermore, the timing of most of the pulses were within 1 to 2 mo of some period of spawning activity, which is consistent with the relatively short larval life of this species (Anderson 1965).

There were substantial differences in the overall levels of recruitment between the populations. The intertidal population received double the number of recruits than were found subtidally, reflecting the different overall densities of the 2 areas. The direct effect of differences in the rates of recruitment on the population dynamics of a species within different habitats has also been found for Patella vulgata (Lewis \& Bowman 1975, Thompson 1980, Workman 1983), Acmaea scabra (Sutherland 1970), Notoacmaea petterdi (Creese 1980b), Cellana tramoserica (Fletcher 1984b) and Patelloida mufria (Fletcher 1984c). Such differences in the rate of recruitment among habitats is either the result of differential settlement of larvae into areas, or from differential mortality of these newly settled juveniles before they could be censused. As with most other studies of marine invertebrates, the phenomenon of settlement was not observed; therefore, I could not distinguish between these 2 alternatives. Underwood (1979) and Keough \& Downes (1982), point out that many studies have failed to recognise this distinction, therefore making any conclusions less reliable. Nevertheless, many factors have been found which correlate with the pattern of recruitment of gastropods within intertidal regions (see Underwood 1979 and Branch 1981 for reviews).

Many of the factors which could influence recruitment within intertidal regions will not apply in subtidal locations. Moreover, the factors that might have been relevant did not appear to be important in this study. Thus, the intertidal population of Patelloida alticostata might be expected to have had decreased recruitment due to the deleterious effects of desiccation and also from the presence of more adults, yet this population had greater recruitment than the subtidal population. A similar pattern of greater recruitment in intertidal regions than subtidally was found by Fletcher (1984b) for Cellana tramoserica. It has been found that the presence of sea urchins Centrostephanus rodgersii in the subtidal areas has a deleterious effect on the recruitment of $P$. alticostata (Fletcher 1987). The sea urchins, whilst feeding, may crush the small $P$. alticostata recruits. Thus it is possible that the actual number of settlers in the subtidal region was the same or even greater than occur intertidally. In contrast, recruitment of another species of limpet in this area, Patelloida mufria, was found to be substantially greater in subtidal than intertidal locations despite the presence of the sea urchins (Creese 1978, Fletcher 1984c).

\section{Growth}

Both methods of estimating growth (marked animals and cohort analysis) yielded similar results. Subtidal individuals of Patelloida alticostata reach $20 \mathrm{~mm}$ shell length after $1 \mathrm{yr}$, whereas in the intertidal region an individual attains only $14 \mathrm{~mm}$. These were, respectively, the sizes at which sexual maturity was reached at the 2 sites. Thus, in this species, maturity was attained at a certain age rather than size. This pattern differs from that found for Cellana tramoserica (Fletcher 1984b), where all 4 populations from the different habitats matured at approximately $20 \mathrm{~mm}$ shell length, despite the varying lengths of time taken to reach this size ( 3 to $9 \mathrm{mo}$ ). Such variations have been interpreted as evidence of species conforming to one or other type of 'strategy' (Stearns 1976). 
The differences in the rate of growth of the 2 populations continued after the first year with subtidal individuals reaching $40 \mathrm{~mm}$ after $4 \mathrm{yr}$ with a maximal size of $48 \mathrm{~mm}$ ( 6 to $7 \mathrm{yr}$ old). Intertidally, individuals reached a size of only $22 \mathrm{~mm}$ after approximately $3 \mathrm{yr}$. This rate for the intertidal population was, nonetheless, faster than that reported by Creese (1981) for a similar population at this site and for a more southerly intertidal population (Parry 1982b). The differences in individual growth between the 2 habitats in the present study are possibly a result of the differences in their respective population densities. Such negative correlations between the rate of growth and population density from unmanipulated populations have been found in many studies (Sutherland 1970, Branch 1975, 1976, Choat 1977, Thompson 1979, 1980, Creese 1980b, Workman 1983, Fletcher 1984b, 1984c). Furthermore, experimental manipulations have confirmed that the growth and condition of many species of gastropods, including Patelloida alticostata, are adversely affected by increased densities (Sutherland 1970, Underwood 1976, 1978, 1984a, Choat 1977, Creese 1980b, Creese \& Underwood 1982, Fletcher \& Creese 1985).

\section{Mortality}

The mortality rates for the 2 populations of Patelloida alticostata appeared to be positively related to their density, but not to the growth rates of the individuals (as suggested by Ebert [1982] and Parry [1982b]). This was similar to most other intraspecific studies of limpets, whereby mortality has also been found to be negatively correlated with growth but positively related to the population density (Sutherland 1970 , Branch 1974, Creese 1980b, Fletcher 1984b). Similar changes in individual mortality rates at experimentally increased densities have been found for many species of gastropods (Underwood 1976, 1978, 1984a, Creese \& Underwood 1982, Fletcher \& Creese 1985) with a shortage of algal food leading to starvation being cited as the most likely cause (Underwood 1978, 1979, 1984a).

The intertidal population of Patelloida alticostata could also have been affected by desiccation or by extremes in air temperature, for the density of the adults declined considerably during each summer. This was also found by Creese $(1978,1981)$ and both factors have been cited as important sources of mortality for other species (Sutherland 1970, Branch 1975, Parry 1977, 1982b, Creese 1978, 1980b, 1981). Underwood (1984b), however, suggested that these patterns of increased mortality in summer are probably also related to the shortage of algal food in this period and by the condition of the individuals prior to the onset of hot weather.

\section{Reproductive cycles}

Both populations of Patelloida alticostata spawned periodically during the course of monitoring. This was indicated by both a decrease in the gonad index and also by histological examination of the ovaries. The use of more than one technique in the description of the reproductive activity of a population greatly enhances the reliability of determinations of the timing of major events (Branch 1974, Creese 1980a, Creese \& Ballantine 1983).

The reproductive cycles of the 2 populations were remarkably similar, despite the large differences in many of their biological characteristics. This synchrony in the pattern of spawning among populations inhabiting heterogeneous habitats has also been reported for the limpets Patella vulgata (Orton et al. 1956, Workman 1983), Cellana tramoserica (Fletcher 1984a) and Patelloida mufria (Fletcher 1984c). Sutherland (1970), however, found that high and low intertidal populations of Acmaea scabra had very different temporal patterns of spawning.

The timing of spawning activity for Patelloida alticostata in this study was only vaguely similar to that found by Creese (1980a) for the intertidal population. He found that $P$. alticostata spawned twice during the year in February to March and May to July. In this study, the major periods of activity were in November 1981, May 1982 and October 1982. Furthermore, Parry (1982a) found that a more southerly population of $P$. alticostata had only one period of spawning activity, in February. Thus, there appears to be differences in the time of spawning among years and locations for this species which have also been found for P. vulgata (Bowman \& Lewis 1977, Thompson 1980); for Cellana tramoserica (compare results from Underwood 1974, Parry 1982a and Fletcher 1984a) and Acmaea insessa (Choat \& Black 1979).

Following spawning, the gonads did not regress nor was there resorption of oocytes, and regeneration appeared to begin immediately afterwards, which has also been found in studies on other limpet species (Branch 1974, Underwood 1974, Creese 1980a, Creese \& Ballantine 1983, Fletcher 1984a).

\section{Reproductive effort}

There has been a considerable amount of discussion concerning the correct method for the calculation of RE (reproductive effort). Hirshfield \& Tinkle (1975) suggested that RE was best measured by the calculation of energy budgets and they cited a number of criticisms against the use of any estimates based solely on biomass. For limpets, however, many of these criticisms 
are not applicable, or they can be circumvented by periodic monitoring (Parry 1982b, Fletcher 1984a). Furthermore, when both methods of calculating RE were compared (Parry 1982a), similar results were obtained. Even in cases where the value of RE may differ between the 2 methods, there is some doubt as to whether this is due to the inadequacy of the biomass method or merely evidence that energy allocation is only indirectly related to reproduction (Parry 1982a). Moreover, it is probably of greater ecological relevance to know what proportion of biomass is represented by spawn, rather than some calorific value. This is especially true if, during a year, the weight of gametes released exceeds the total body weight (e.g. Patella peroni, Parry 1982b; Cellana tramoserica, Fletcher 1984a).

Variations in RE among species have often been viewed as expressions of different life history strategies or patterns (Stearns 1976, Grahame \& Branch 1985). It has been suggested that RE should be positively correlated with the rate of mortality of a population (e.g. Williams 1966). Where intraspecific variation has been investigated, many studies have found large differences in the RE among populations inhabiting different areas (e.g. Branch 1974, Snell \& King 1977 , Hughes \& Roberts 1980, Stearns 1980, Brown 1983, Fletcher 1984a). In many of these studies, however, RE was not correlated positive with the rate of mortality.

In this study, there was little difference in the average RE of individuals from the 2 populations of Patelloida alticostata, despite the large differences found in their rates of mortality and growth. This pattern was also found by Sutherland (1972) for 2 populations of Acmaea scabra. So, instead of having great flexibility in RE, as was found for Cellana tramoserica (Fletcher 1984a), the individuals of $P$. alticostata appeared to have a constant relative investment into gonad material. It appears, therefore, that the reproductive effort of different populations of the same species are not always correlated in any predictable way with other variables such as growth or mortality. Furthermore, many of the variations which have been observed in intraspecific studies may merely represent phenotypic plasticity among genetically similar individuals (e.g. Snell \& King 1977, Fletcher 1984a). Consequently, such studies do not necessarily predict the 'trade-offs' among functions (i.e. growth, mortaility, reproductive effort) which would occur due to selection. Instead, these studies address different questions (Reznick 1982); unless any of these variations reflects some underlying genetic difference, there cannot be selective adaptation (Findlay \& Cooke 1983, Fletcher 1984b). Similarly, the fact that little plasticity in a response is found does not indicate that these variables are not subject to selection. To investigate the types of trade-offs assumed in life history theory, genetical correlations among isolated populations may need to be studied (Reznick 1982). But because most species of marine invertebrates have dispersive larval stages, the isolation of different genotypes among localised habitats will be extremely unlikely (but see Murphy 1976). Despite this, investigations of the potential flexibility of the life history of a species are important, especially with regard to the role and interactions of a species in the structure of natural communities. Individuals of species with a flexible biology may reduce the effects of competitive interactions, or withstand periods of adverse environmental conditions, more effectively than species which have relatively inflexible biological patterns. Determining the range of biological responses of a species to differing environmental conditions should, therefore, enable better predictions to be made concerning the effects of perturbations on the community.

Acknowledgements. This study was done whilst the author was in receipt of a Commonwealth Postgraduate Scholarship and a University of Sydney research grant. Part of the analysis was done when the author was funded by an ACIAR project. I thank D. Fletcher for assistance in the field and laboratory, I. W. Brown for organising the production of this paper, and G. E. Davidson for typing the manuscript. Also thanks to A. J. Underwood, and to 3 anonymous referees whose comments greatly helped the clarity of this manuscript.

\section{LITERATURE CITED}

Anderson, D. T (1965). The reproduction and early life histories of the gastropods Notoacmaea petterdi (Ten.Woods), Chizacmaea flammea (Quoy \& Gaimard) and Patelloida alticostata (Angas) (Fam. Acmaidae). Proc. Linn. Soc. N.S.W. 90: 106-114

Ballantine, W J. (1961). The population dynamics of Patella vulgata. Ph.D. thesis, Queen Mary College, London Univ.

Beverton, R. J. H., Holt, S. J. (1957). On the dynamics of exploited fish populations. Fishery Invest. Lond., Ser. II, Vol. 19: 1-533

Black, R. (1977). Population regulation in the intertidal limpet Patelloida alticostata (Angas, 1865). Oecologia (Berl.) 30 : 9-22

Bowman, R. S., Lewis, J. R. (1977). Annual fluctuations in the recruitment of Patella vulgata L. J. mar. biol. Ass. U.K. 57 : 793-815

Branch, G. M. (1974). The ecology of Patella (L.) from the Cape Peninsula, South Africa. 2. Reproductive cycles. Trans. R. Soc. S. Afr. 41: 112-160

Branch, G. M. (1975). Intraspecific competition in Patella cochlear Born. J. Anim. Ecol. 44: 263-282

Branch, G. M. (1976). Interspecific competition experienced by South African Patella species. J. Anim. Ecol. 45: 507-530

Branch, G. M. (1981). The biology of limpets: physical factors, energy flow, and ecological interactions. Oceanogr. mar Biol. A. Rev. 19: 235-380 
Brown, K. M. (1983). Do life history tactics exist at the intraspecific level? Data from freshwater snails. Am. Nat. 121 $871-879$

Cassie, R. M. (1954). Some uses of probability paper in the analysis of size frequency distributions. Aust. J. mar Freshwat. Res. 5: 513-522

Choat, J. H. (1977). The influence of sessile organisms on the population biology of three species of acmaeid limpets. $\mathrm{J}$. exp. mar. Biol. Ecol. 26: 1-26

Choat, J. H., Black, R. (1979). Life histories of limpets and the limpet-Laminarian relationship. J. exp. mar. Biol. Ecol. 41: 25-50

Creese, R. G. (1978). Ecology and reproductive biology of intertidal limpets. Ph.D. thesis, Univ, of Sydney

Creese, R. G. (1980a). The reproductive cycles and fecundities of four common eastern Australian archaeogastropod limpets (Mollusca: Gastropoda). Aust. J. mar. Freshwat. Res. 31: $49-59$

Creese, R. G. (1980b). An analysis of distribution and abundance of populations of the high-shore limpet, Notoacmea petterdi (Tenison-Woods). Oecologia (Berl.) 45: 252-260

Creese, R. G. (1981). Patterns of growth, longevity and recruitment of intertidal limpets in New South Wales. J. exp. mar. Biol. Ecol. 51: 145-171

Creese, R. G., Ballantine, W. J. (1983). An assessment of breeding in the intertidal limpet, Cellana radians (Gmelin). J. exp. mar. Biol. Ecol. 67: 43-60

Creese, R. G., Underwood, A. J. (1982). Analysis of inter- and intra-specific competition amongst intertidal limpets with different methods of feeding. Oecologia (Berl.) 53: 337-346

den Boer, P. J. (1968). Spreading the risk and stabilisation of animal numbers. Acta Biotheor 18: 165-194

den Boer, P. J. (1981). On the survival of populations in a heterogeneous and variable environment. Oecologia (Berl.) 50: 39-53

Ebert, T. A. (1973). Estimating growth and mortality rates from size data. Oecologia (Berl.) 11: 281-298

Ebert, T. A. (1982). Longevity, life history, and relative body size in sea urchins. Ecol. Monogr. 52: 353-394

Findlay, C. S., Cooke, F. (1983). Genetic and environmental components of clutch size variation in a wild population of the lesser snow goose (Anser caerulescens caerulescens). Evolution 37: 724-734

Fisher, R. A. (1930). The genetical theory of natural selection (Rev. edn, 1958). Dover Press, New York

Fletcher, W. J. (1984a). Variability in the reproductive effort of the limpet, Cellana tramoserica. Oecologia (Berl.) 61 (2): $259-264$

Fletcher, W J. (1984b). Intraspecific variation in the population dynamics and growth of the limpet, Cellana tramoserica. Oecologia (Berl.) 63: 110-121

Fletcher, W. J. (1984c). Experimental population ecology of sublittoral grazers in New South Wales. Ph.D. dissertation, Univ. of Sydney

Fletcher, W. J. (1987). Interactions amongst subtidal Australian sea urchins, gastropods and algae: effects of experimental removals. Ecol. Monogr. 57: 89-109

Fletcher, W. J., Creese, R. G. (1985). Competitive interactions between co-occurring herbivorous gastropods. Mar Biol. 86: 183-191

Goodman, D. (1979). Regulating reproductive effort in a changing environment. Am. Nat. 113: 735-748

Grahame, J., Branch, G. M. (1985). Reproductive patterns of marine invertebrates. Oceanogr. mar Biol. A. Rev. 23: 373-398

Hirshfield, M. F., Tinkle, D. W. (1975). Natural selection and the evalution of reproductive effort. Proc. natn. Acad. Sci. U.S.A. 72 : $2227-2231$

Hughes, R. N., Roberts, D. J. (1980). Reproductive effort of winkles (Littorina spp.) with contrasted methods of reproduction. Oecologia (Berl.) 47 130-136

Keough, M. J., Downes, B. J. (1982). Recruitment of marine invertebrates - the role of active larval choices and early mortality. Oecologia (Berl.) 54: 348-352

Lewis, J. R., Bowman, R. S. (1975). Local habitat induced variations in the population dynamics of Patella vulgata $\mathrm{L}$. J. exp. mar. Biol. Ecol. 17: 165-203

McKillup, S. C., Butler, A. J. (1979). Modification of egg production and packaging in response to food availability by Nassarius pauperatus. Oecologia (Berl.) 43: 221-233

Murphy, P. G. (1976). Electrophoretic evidence that selection reduces ecological overlap in marine limpets. Nature, Lond. 261: 228-230

Orton, J. H., Southward, A. J., Dodd, J. M. (1956). Studies on the biology of limpets. II. The breeding of Patella vulgata L. in Britain. J. mar. biol. Ass. U.K. 35: 149-176

Parry, G. D. (1977). Life-history strategies of five species of intertidal limpet. Ph. D. dissertation, Univ. of Melbourne

Parry, G. D. (1982a), Reproductive effort in 4 species of intertidal limpet. Mar. Biol. 67: 267-282

Parry, G. D. (1982b). Evolution of the life-histories of four species of intertidal limpet. Ecol. Monogr. 52: 65-92

Reznick, D. (1982). The structure of guppy life histories: the trade off between growth and reproduction. Ecology 64: $862-873$

Richards, F. J. (1959). A flexible growth function for empirical use. J. exp. Bot. 10: 290-300

Snell, T W., King, C. E. (1977). Lifespan and fecundity patterns in rotifers: the paradox of reproduction. Evolution 30: $882-890$

Steams, S. C. (1976). Life-history tactics: a review of the ideas. Q. Rev. Biol. 51: 3-47

Stearns, S. C. (1980). A new view of life history evolution Oikos 35: 266-281

Sutherland, J. P. (1970). Dynamics of high and low populations of the limpet Acmaea scabra (Gould). Ecol. Monogr. 40: $169-188$

Sutherland, J. P. (1972). Energetics of high and low populations of the limpet Acmaea scabra. Ecology 53: 430-437

Thompson, G. B. (1979). Distribution and population dynamics of the limpet Patella aspera in Bantry Bay, Ireland. J. exp. mar. Biol. Ecol. 40: 115-136

Thompson, G. B. (1980). Distribution and population dynamics of the limpet Patella vulgata in Bantry Bay, Southwest Ireland. J. exp. mar. Biol. Ecol. 45: 173-218

Underwood, A. J. (1974). The reproductive cycles and geographical distributions of some common Eastern Australian prosobranchs (Mollusca. Gastropoda). Aust. J. mar. Freshwat. Res. 23: 63-88

Underwood, A. J. (1975). Comparative studies on the biology of Nerita atramentosa (Reeve), Bembicium nanum (Lamark) and Cellana tramoserica (Sowerby) (Gastropoda Prosobranchia) in Southeast Australia. J. exp. mar. Biol Ecol. 18: 153-172

Underwood, A. J. (1976). Food competition between age classes in the intertidal Neritacean Nerita atramentosa (Reeve) (Gastropoda: Prosobranchia). J. exp. mar. Biol. Ecol. 23: 145-154

Underwood, A. J. (1978). An experimental evaluation of competition between three species of intertidal Prosobranch gastropods. Oecologia (Berl.) 33: 185-202

Underwood, A. J. (1979). The biology of gastropods. Adv. mar Biol. 16: 111-210 
Underwood, A. J. (1984a). Vertical and seasonal patterns in competition for microalgae between intertidal gastropods. Oecologia (Berl.) 64: 211-222

Underwood, A. J. (1984b). The vertical distribution and seasonal abundance of intertidal microalgae on a rocky shore in New South Wales. J. exp. mar. Biol. Ecol. 78: 199-220

Underwood, A. J., Denley, E. J., Moran, M. J. (1983). Experimental analysis of the structure and dynamics of mid-shore rocky intertidal communities in New South Wales. Oecologia (Berl.) 56: 202-219

Williams, G. C. (1966). Natural selection, the costs of reproduction, and a refinement of Lack's principle. Am. Nat. 100: $687-690$

Workman, C. (1983). Comparisons of energy partitioning in contrasting age-structured populations of the limpet Patella vulgata L. J. exp. mar Biol. Ecol. 68: 81-104

This article was presented by Dr R. N. Hughes; it was accepted for printing on May 11, 1987 